\title{
See No Evil Write No Evil: Sexual Deviance In African Literature During Colonialism
}

\author{
Wazha Lopang \\ Department of English, University of Botswana
}

Received: 08-07-2014

doi:10.7575/aiac.ijclts.v.2n.4p.1
Accepted: 18-08-2014

Published: 01-10- 2014

\begin{abstract}
This paper argues that writers of African literature during colonialism differed in their portrayal of sexuality, particularly that which was considered deviant by nature, because of their need to build an 'upright' African image, no matter how artificial this was. The paper looks at how the political environment dictated sexual expression amongst characters and that the urban setting was more candid in its narrative style. There was also a total blackout on homosexuality between characters and where this took place, it was presented as something that was alien to the African culture in general and to the personality in particular. Writers who depicted pre-colonial settings limited sexuality to procreation and as a comment to the African's link with the ancestors. There is also a correlation between the geographic location of texts and the degree of sexual expression that the writer engages in. As such the paper argues that sexual deviance is depicted as a matter of geography over and above thematic concerns.
\end{abstract}

Keywords: sexuality, colonialism, setting, African image

\section{Introduction}

To read the earlier literature by African writers that reflected on the colonial (and pre-colonial) experience, one would be forgiven to believe that the societies they sought to present to the world were prudish when it came to sex and sexuality. In addition to this, one would also believe that sexual lifestyles such as homosexuality were indeed a myth and where they existed, these could be compartmentalized as part of the subculture of the main colonial socialization thrust. A reader of these earlier texts would also notice the glaring lack of heterosexual sexual expression amongst the characters.

Chinua Achebe's Things Fall Apart (1959) is a classic example of a text that was ultra conservative in its image of black sexuality. The narrative style's desire to depict a cultural verisimilitude of the Igbo is such that there is a conscious need to do so in a manner that will bring dignity and honor to the African image that the colonial perspective had desecrated in Conrad's Heart of Darkness (1902). One felt that the need to correct the vision of the native was for Achebe one that had to be done in a manner that would steer away from European clichés of the native as an individual who pleaded to his basic instincts. Innes (1990) states that "the title of Things Fall Apart with its reference to Yeats' concept of vast historical cycles, implies that in challenging Cary's story (Mister Johnson) he knew he was also challenging a whole vision of history, a set of values and a particular ordering of society" (Innes, 13). It is thus not surprising that Things Fall Apart avoids issues of sexual expression. It was not just a narrative technique but a political statement that there was more to Africans than seeing them as lust filled animals barely operating on the margins of sexual restraint. These fears were not unfounded given the missionary assessment of the native at the time. Perhaps the most damning assertion that supports this view is provided by Dudley Kidd's theory of arrested development. This ethnologist, according to Lewis and Steyn (2003) stated that,

Black children's ability to absorb knowledge far outstripped their European counterparts, but with the onset of puberty, this capacity declined and was surpassed by that of white adolescents due to black adolescents' absorption with "nutritive and sexual needs." (Kidd, 1904: 277-278; 280-282) (Lewis and Steyn, 104)

A case can be made that Achebe's reason (and that of other writers who sought to bring to attention an alternative view of the African identity) to omit sexuality from his text was to shatter the stereotype of the insatiable African. Thus, the choice was both a political as well as a moral one. It is perhaps understandable why Things Fall Apart does not comment on sexuality that commented on black experiences or those that were purportedly introduced by the European. This self imposed sexual censure is despite the fact that according to Aldrich (2003) the colonial penetration of Africa brought along its fair share of male on male sexual activity particularly of the inter-racial kind. Epprecht (2004) puts this into context by stating that "the first known European in Zimbabwe alleged to have had homosexual tendencies was none other than Cecil John Rhodes, founder of the colony that eventually took his name." (104). However, even earlier than this Rudwick reports that "pre-historical cave paintings in South Africa document homosexual activity from the earliest of times." (96). There was, therefore, many forms of sexual expression that Achebe could have included in his take on missionary. However, homosexuality aside, in terms of documenting sexual activity that promotes masculine culture the earlier African writers appear reluctant to illustrate such activity. What one is assured of is the equating of 
polygamy with fertility and by implication manhood. In Achebe's text, for instance, heterosexual family life is promoted and fertility is enhanced by the practice of polygamy which is seen as a barometer of wealth as well as an indicator of sexual prowess. Murray and Roscoe (1998) seem to suggest that the missionary education that African writers received influenced how writers approached issues of sexuality in general, including homosexual episodes in their writing. Murray and Roscoe state that,

Sensitized by missionaries and western education, defensive in the face of stereotypes of black hypersexuality, and resentful of sexual exploitation in colonial institutions, the first generation of post colonial Africans was extremely reluctant to discuss the subject of homosexuality. For most the negotiation of African identity remained tied to European standards of morality. (xvi)

However, with respect to Achebe one can argue that this writer did not want African society to define itself in relation to 'European standards of morality' and Things Fall Apart sought to depict a community that had an identity, a respected culture, at least internally, and before the missionary influence compromised it. Thus, to accuse Achebe of not portraying homosexuality or commenting on it in some way because he was carrying a European moral beacon would be misguided. It is fair to say that either Achebe was unaware of homosexual practices at the time or he chose to focus on what he felt was more pressing. Yet despite this lack of acknowledgement of homosexuality in the West African text there is proof that incidents of such were prevalent in places such as the Cape which was the frontier through which the white man conquered Africa.

It is in the earlier South African writing that one sees a disparity between what was happening in society and what chose to be represented in texts by African writers. The awareness that same sex relationships were taking place seems to have been present before the Missionary set foot on the African shores. Epprecht (2004) reveals that in the Cape, "charges of male-male sexual assaults by Bantu speakers upon their countrymen began to crop up in British courts as early as 1860." (57). However, even outside the so-called frontier towns and much earlier than this, episodes of homosexuality were recorded thus dismissing the view that such practices were the unfortunate product of a clash of cultures between Bantus and Europeans. Falk (1998) states that "as early as 1719, Peter Kolb (1719:362) mentioned Khoi-khoi males, called koetsire, who were sexually receptive with other males." (173). There were also cases of lesbianism in that "in the 1920s, Falk reported that homosexuality among khoisan speakers was fairly common, especially among young married women." (173). Sol Plaatje's Mhudi (1930) came out at a time when Falk's comments were still topical and one would expect Plaatje to make reference to it if only because his text talks of a tribal group in transition. This is not the case. Mhudi steers clear of sexual episodes of any kind and in line with Plaatje's missionary upbringing, it preaches the moral ideal of forgiveness, love and tolerance. One may argue that the missionary education that Plaatje benefited from did influence both the content matter and the manner in which it was delivered. As Venter (1992) aptly puts it, "Christianisation went hand in hand with educational provision as the latter led to a better understanding of the former." (5). It is perhaps only Wilbur Smith, that writer of popular fiction, who in his writings of the Cape and the African interior mentions gay characters and illustrates homosexual experiences of the indigenous blacks.

\section{West African Literature and sexual expression}

One understands that even when African writers depict heterosexual experiences, the narrative is functional at best. For instance, the closest one gets to reading anything sexual in Things Fall Apart is the description of when Okonkwo prepares to sleep with Ekwefi after she had fled from her husband, Anene: "Even in those days he was not a man of many words. He just carried her into his bed and in the darkness began to feel around her waist for the loose end of her cloth." (Achebe, 78). Other than that the issue of sexuality is not discussed in the text. This approach by Achebe to sexuality changes with Anthills of the Savannah (1987) though one would wonder if this is due to the text's urban setting. Perhaps it is the urban setting that makes episodes of sexual expression among characters quite liberal. Achebe's narrative technique is that the more educated the characters are the more sexually expressive they seem to be and this is true in most texts by writers of his generation. There is a direct correlation between the two concepts of education and sexual expression in African literature. More importantly, it appears that education empowers the female character to take on a more dominant role. Consider this description of lovemaking in Anthills of the Savannah between Chris and Beatrice: "More than once he had slipped on the steep banks and she had pulled him up and back with such power and authority as he had never seen her exercise before. Clearly this was her grove and these her own peculiar rites over which she held absolute power." (Achebe, 114) The description is poetic but leaves no doubt as to who is the more experienced of the two. This is a long way from the patriarchal remark made by one of the characters in Things Fall Apart during a discussion on marriage, "The world is large," said Okonkwo. "I have even heard that in some tribes a man's children belong to his wife and her family." "That cannot be," said Machi. "You might as well say that the woman lies on top of the man when they are making the children." (Achebe 1958, 52). It can be argued therefore, that setting influences the depiction of sexuality by African writers. One simply cannot picture Okonkwo in this position.

Ferdinand Oyono also chooses to portray his male indigenous characters as sexually disinterested during colonialism. There is thus, for the reader, a realization that a discourse on sex and society had no role to play in telling the African experience; that it was anathema to building a profile of the African image. The black characters in Houseboy (1966), which is set in French colonial Africa, do not have a sexual drive that is triggered independently of white mannerisms. The book tells the story of Toundi, an indigenous boy who rejects his own family in favour of staying with the white missionaries. He becomes a houseboy or servant for a prestigious family but over time he becomes disillusioned by the life he has chosen and he dies a broken man, falsely accused of theft by the whites. In the text it is his employers the Madam and the Commandant who provide the sexual thrust of the text. In fact it is the whites who, either among 
themselves or with the consent of black girls, show a sexual identity missing in the African. Toundi is not presented as judgmental of the inter-racial sex nor does he condemn the infidelities he witnesses frequently. For instance, it is Kalisia who says to Toundi of her white lover Monsieur W.C, "When you meet him you don't lift your hat, you lift your skirt." (101). Houseboy depicts an unusual relationship between the black man and sexuality. None of the black males in the text are shown to have sexual feelings for the opposite sex. It is only the retired soldier Mekongo who brags about his sexual conquests with European women. All the other characters show an unrealistic aversion towards black women. Toundi for instance, is approached by Sophie and Kalisia on two separate occasions and they make it clear in no uncertain terms that they desire him sexually. On both occasions he turns down their advances. African writers consciously set out to depict situations where the male characters in their colonial texts did not see sex as enjoyment. Sex was first and foremost a tool for procreation. There is thus a conscious effort from Oyono, Amadi and Achebe to present the male form as being anathema to sexual enjoyment.

\section{Sexuality and its place in the West African ethnographic novel}

In the ethnographic novel and for reasons already mentioned at the beginning, the writer avoids such descriptions as we read of Chris and Beatrice in Anthills of the Savannah. For instance, despite its suggestive title, Amadi's The Concubine (1966) steers clear of any sexual antics. The text traces the problems faced by the male characters in their futile quest to win over the hand of a beautiful though cursed woman. Even the language used to describe lascivious males is tame. We are told that Madume has "big eyes" regarding his sexual interest in Ihuoma, the troubled yet beautiful maiden of the story. Nnadi, Ihuoma's brother in law confronts Madume and says, "You big-eyed fool, how dare you touch Ihuoma?" (Amadi, 69). Not only is the sexual innuendo muted, so is the language. It is a text that works a lot on suggestive phrases and diction in keeping with the traditional dignity of village life. This is essentially the case with texts that are written in the sixties, especially if the setting is traditional. The implication is that African societies strictly saw sex and sexuality through a lens of procreation. Armah's Two Thousand Seasons (1973) is a sweeping tale of how slavery corrupted African culture and identity. The novel provides an exception to the notion that sexual expression is more pronounced in urban environments. However, it still echoes an important sentiment. Two Thousand Seasons underlines the point that sexual vice was a foreign side effect of cross cultural influence. The narrative style makes it clear that the Arabs, referred to as predators, have sexual tastes that are excessive, grotesque and self centred. These predators are bisexual and seem to relish sexual orgies. One of them, Faisal, is unfulfilled with the attentions of the beautiful Azania underneath him and he calls his askari for further stimulation,

He strode forward at the urgent call and in a moment was naked upon his master's back, ploughing the predator's open arsehole while the master tried to keep his forgetful penis in Azania. Then the joy of having his askari mount him overwhelmed all Faisal's senses. (Armah, 23)

There is also Hassan who is described as having sexual intercourse with six women using his penis, tongue, teeth, toes and fingers for penetrating these women. A good feature of these earlier texts then is that what can be construed as deviant sex, that which is bizarre or extremely unusual, was presented as alien to the culture and practices of the indigenous people. Sexual practices are presented as coming from outside, as being inevitable aside effects of slavery, colonialism or other such malice.

It is only when one ventures to those texts that have an urban setting that characters are shown to have very liberal attitudes towards sex. Ayi Kwei Armah's Fragments (1969) is a typical example where urban life suggests a more sexually pervasive society but one which it seems is so because of cultural integration. The novel is about societal values are in a downward spiral and the protagonist Baako finds it extremely difficult to find meaning in his life following his return from overseas. Baako, an educated African, has a sexual encounter with the Puerto Rican woman, Juana, in the sea. This in itself is a statement to the effect that sex and the public expression of such can only be attributed to an association with foreigners or to the fact that one of the parties has studied overseas. This 'been to' then has learned a lot while in Europe besides western education. The narrative style is more descriptive and far much is offered to the mind than Achebe and Amadi,

She was surprised when he moved his left hand and in a swift movement pushed a finger deep in her arse, but the unpleasant feeling was momentary; in its place rose a sensation of queerly heightened sweetness as she felt the membrane inside her caught between Bako's finger and penis; he turned the finger round toward her back, groping in a soft reach for the base of her spine, and that was when she came - (Armah, 125).

This vivid sexual encounter is one of the first in African literature to depict a woman being simultaneously vaginally and anally penetrated. It is a bold description and the use of the word 'arse' leaves no doubt to the sexually innocent where this penetration is taking place. What is more interesting is Juana's reaction to this sexual experience. There is no indication that she feels shamed by the act or that it is an experience of something taboo. Though there is an 'unpleasant feeling', it is 'momentary' and she is not described as recoiling from it. There is no doubt that this anal penetration is a first for Juana but she does not question Baako as to why he does this to her. The idea one gets is that this novel form of penetration is part of the sexual experience she is having and not something that should be looked at as additional or different to the lovemaking itself. Her only question to Baako is to find out whether this man has prior experience to making love in the sea. The important part of Armah's narrative is that there is no categorising of sexual activity as taboo or conventional. It is a package with different parts to it all intended to bring pleasure to the consenting adults. Wright (1990) makes a comment about Baako's persecution by society in this text arguing that this is "designed to exorcise a general impotence, and in the implication is that this society is jealously resentful of any indigenous creative energy or uniqueness, and tries to kill or render barren what it cannot itself create." (Wright, 33). Despite all that affects 
Baako politically and socially his impotence in the sexual arena is a non issue and the sea with its connotation of life and renewal at least goes against Wright's assertion.

\section{The East African ambiguity towards sex}

The East African writers of African Literature generally tend to be controlled in their use of sexual diction although this depends on which period you are looking at. For instance, Ngugi's male characters in his colonial piece, The River Between (1965) are nothing like those we see in his post colonial tale Devil on the Cross (1982). Typical of Ngugi's work orality is a major feature in these novels. For instance, both these texts display how proverbs can be used to reinforce social position and ideology but it is in Devil on the Cross that the proverb shows its versatility as a promoter of vice. For instance, in Gituta wa Gataanguru's testimony during a secret meeting of all the thieves of Kenya, he boasts, "I have two mistresses, for you know the saying that he who keeps something in reserve never goes hungry." (Ngugi, 99) Generally though, language use is carefully controlled in dealing with the sexual. This is true as well for those who bring attention to gender relations. The narrative style of Farah's Sardines (1992) is a case in point. Though the story is set in an urban environment there is none of the sexual explicitness one finds in Armah's work. This could be mainly because the setting is an Islamic one and one which is predictably patriarchal. However, it goes to show that setting may not necessarily show an inclination towards a particular expression of sexuality. Medina the educated female character of the text is at odds with her husband Samater who has become part of the General's regime. The two become estranged and Farah shows how sexuality expresses itself amidst political and marital tension. The threat of the Islamic husband being morally corrupted during his wife's absence is portrayed as an external one, outside the spiritual framework of Islamic principles. There is a scene where Samater is watching Atta, the black American girl sleeping on her back with her sex exposed. This girl's erotic nature causes Samater to fantasize that Atta would probably devour him sexually,

But dare he go anywhere near Atta who would in all likelihood welcome him in, open her legs wider apart, guide his fingers up the curled lips of her womanhood and with her free hand conduct his member inwards? (Farah, 191).

The narrative is clear that Atta is a person who is not unversed in the ways of seduction. Furthermore, sleeping with Samater would put to bed some of his personal demons such as his mother's negative opinion of his manhood. However, there is a pattern here not dissimilar to what is shown in Fragments. It needs a foreigner to ignite embers of sexuality in an otherwise dour society. The assumption is that the indigenous population offers no titillating sexual outlet and must look outside it to be fulfilled. Atta and Juana are not natives of the setting they find themselves in yet both of them show receptiveness towards sexual exploration. One does this through seduction in a private residence, the other through experimentation in a public place. These two texts depict male female interaction between local men and foreign women and one wonders if sexual attitudes in African Literature are relaxed only in these scenarios.

\section{Southern Africa}

\subsection{Self love and politics in Zimbabwean Literature}

The colonial atmosphere in Zimbabwe was admittedly more psychologically scarring than was the case in say, West Africa, if one considers the writings of Shimmer Chinodya and Dambudzo Marechera. Their texts (with equally pessimistic titles) are set against the backdrop of a colonial entrenchment that purges the moral and mental pathos and depict young boys being exposed to masturbation and reacting not with revulsion but with desire towards the phallic symbol and the activity itself. Marechera's House of Hunger (1978) narrates the way in which sexual tension and violence in pre-independence Zimbabwe reflects the general psychological state of the country. It depicts how a family becomes a symbol of the graphic transition that faces a country on the verge of self rule. Marechera's narrative describes Peter's public orgasm and its effect as follows, "And moaning like something out of this world, he came and came like new wine that cannot be contained within old cloth. The gang grew closer and closer and sighed. I swallowed thickly, but my mouth was dry. And my mouth, it seems, has been dry ever since." (Marechera, 49) For these writers sex becomes part of the colonial metamorphosis towards independence. Sex is not so much a symbol of colonial degeneracy as it is a realistic characteristic of the African condition during that period of soul searching and of finding one's place in the white man's framework. Though House of Hunger and Chinodya's Harvest of Thorns (1989) steer clear of homosexuality it is clear that sexuality among adolescents is treated with an honest brutality not seen in West African texts during the colonial period. These sexual episodes are performed in urban settings which might suggest a sexual liberalism that would not be otherwise seen in an African village. However, this in no way assumes that mutual masturbation or voyeurism is a side effect of a white man's urban culture. Both Peter in House of Hunger and Chorosi in Harvest of Thorns show sexual experimentation that comes along with puberty. Harvest of Thorns is about the bitter civil war between the Rhodesian forces and guerrilla fighters. Chinodya's narrative states, "Chorosi who took pride in showing off a bottle of Vaseline filled with three months of sperm." (Chinodya, 91) The public displays of self pleasuring are not to be blamed on the psychological scourge of colonialism but should be seen as natural coming of age rituals. Benjamin's awareness of masturbation while at boarding school becomes a comment on how cloistered his parents are and more importantly, how Christianity has created in him an unfulfilled picture of the world.

Sex was something nobody talked to him about, an unspeakable act at best reserved for the functional bedrooms of married people, at worst associated with the drunken beerhall couples he and his sister had jeered at as children. Sex was something existing only in these two extreme forms; there could be no mean to it. (Chinodya, 92) 


\subsection{Apartheid South Africa and liberal sexual expression}

In South Africa female writers are quite adept at expressing sexuality. Nadine Gordimer's novel Burgher's Daughter explores different forms of love, not only the sexual. Interestingly, the urban setting seems to suggest that just like Sardines and Fragments, characters in African Literature are greatly influenced by their setting in terms of sexual freedom and expression.

Burgher's Daughter is about a girl, Rosa, who loses both her parents in the struggle against apartheid. In remaining alone with little supervision in her town house she embarks on a sexual adventure of sorts while still on a quest to ensure her parents are not forgotten by those outside the prison walls.

Burger's Daughter involves a sort of shifting commentary in which the narrative style moves from first person narrative to third person narrative. This is unlike what we see in July's People, which uses third person narrative. This story is about a white family forced to flee their home due to the onset of civil war and seek refuge with their black servant July. While in July's village the Smales undergo introspection of a way of life they had taken for granted, including access to and enjoyment of sex. The difference in the narrative style between the two texts comes about because Gordimer's intention in Burgher's Daughter is to create both a subjective and intimate portrayal of the central character Rosa as she comes to terms with the loss of her parents through imprisonment under the apartheid system. Therefore, this unusual narrative style helps us understand how Rosa deals with her feelings and her relationships.

One could say that just like July's People Gordimer uses flashback here to make the reader try to grasp why Rosa has so many sexual encounters. One is left to wonder whether these experiences are part of a young girl's sexual awakening or if they are a consequence of the independence thrust upon her by the imprisonment of her parents. What is interesting is the manner in which Gordimer describes these sexual encounters. One such example is Rosa's relationship with Markas, the Swedish friend of hers who wanted to make a documentary of her father. Markas is seen as a very passionate person and at the same time as a person who is sexually attracted to Rosa and who stimulates a lot of desire in her. Consider the following description:

The Swede had buttocks tanned as his backs and legs - all of a unity, as if his body had no secrets. He was beautiful. And whether or not I am, he felt the same about me and could coax from me - that is the only way to describe the pride and appreciation, the simplicity of his patience and skill - three orgasms, one after the other... (Gordimer, 64)

The language here is not explicit in describing the sexual encounter and what we get is an awareness of how Markas affects Rosa and what he does to her in being subtle in describing the encounter itself this is similar to July's People in that the narrator did not dwell on the physical act itself but focused on the uncomfortable nature brought about by the strange environment in which Maureen and Bam where in. However, in Burger's Daughter we have a more detailed and intimate description of love making, unlike July's People here we see the character being fulfilled by the encounter. We also understand that although Rosa enjoys these sexual encounters there seems to be no permanence about them. Markas goes back to Sweden with half hearted promises of organizing a passport for her to join him. We don't see Rosa being unduly affected by his departure in fact she does contemplate if indeed Markas was using her yet being afraid to directly engage the apartheid system. Rosa even remarks, "being the lover of Lionel Burger's daughter for a month or two was the nearest he would ever get to the barricades. I don't mind. What else was I?" (64-65). Unlike Maureen in July's People we see that intimate relations trigger a lot of introspection and soul searching. Here Rosa is able to analyze motives behind sexual encounters as a result of the setting she is in. So the urban environment provides a frame work for this character to understand how she relates to people. In July's People Maureen does not introspect so much, one reason being that her sexual experiences are with her husband. However, a possible reason could be that the rural setting creates a survival reflex in her where getting by each day is enough to occupy her mind.

It is clear that in Burger's Daughter sex and politics are closely entwined, the relationships that Rosa has are directly triggered by her parent's situation. Noel De Witt is a good example of this. As he is one of Rosa's father's associates he has to think of a plan to ensure he keeps in touch with Lionel. The only way he could do this was to be engaged to Rosa. This arrangement is seen as a necessity and a consequence of what people need to do to get by in an apartheid system. Although Rosa does not go into details about any sexual encounters between the two we see how her parents react to this strange situation. Rosa says of her mother, "if she saw, realized - and at least she might have considered the possibility - she didn't choose to see.” (Gordimer, 66).

The power of sex is also displayed in a more blatant form when Rosa visits the prison by drawing attention to her body. She is able to distract the warders in allowing her to give some important notes and gifts to her father.

I trickled perfume between my breasts and cupped some to rub on my belly and thighs. I chose a dress that showed my legs, or trousers and shirt that emphasized my femaleness with their sexual ambiguity. Scent me out, sniff my flesh. Find me receive me. And all this with an unthinking drive of need and instinct that could be called innocent and that you call 'real'. I took a flower with me. Usually the warders would not accept it for him (now and then sentimentality of one of them for 'sweethearts', or the vicarious sexual stir another got from pandering, would move him to pass the gift). (66-67).

Gordimer's style is such that it emphasizes how femininity can drug the senses of men. Therefore, we see that the female body can be used as a weapon to deal with the apartheid system. Sexuality being a tool to negotiate one's way through the symbols of authority. This use of sexuality is different from what one sees in Fragments for instance in that it takes on a political significance. Just like the previous quotation Gordimer is explicit without being over the top in her description. What we see is that Rosa is a resourceful young lady who is able to use her physical gifts to her advantage. 
Rosa's encounters are not limited to the people of her race, we are told that she shared a bed with an African while still young and this shows that love for Rosa goes beyond boundaries of race and is inclusive.

Conrad, a friend of Rosa and a student has a strange relationship with her. Although they are intimate and share a house Rosa seems to allow and even ignore Conrad's wondering libido: "Conrad went off some evenings for Spanish lessons and sometimes came back with the girl who taught him. Those nights he spent in the living room; Rosa, going to work in the morning, stepped round the two of them rumpled among the old cushions and karoos on the floor like children overcome by sleep in the middle of a game." (40). Rosa, therefore, comes across as an individual who doesn't seem to invest emotionally in a man, the fact that another girl is sleeping with Conrad does not affect her. In fact Gordimer's writing style as seen in this quotation makes for an interesting observation. She deliberately omits any emotional reaction on Rosa's part. The language that she uses makes it difficult for a reader to make an emotional connection between Conrad and Rosa. In fact Conrad and his lover are described in innocent terms, "like children overcome by sleep in the middle of the game." (40) We see parallels in this description with the way Marcus and Rosa are described, the physical dominates the emotional connection in both cases and this is a major characteristic of Rosa. As I said earlier the urban setting and the demands it places on Rosa after the loss of her parents is perhaps the reason why she behaves the way she does.

This behavior can also be analyzed in Rosa's interaction with characters from outside South Africa. Here the narrator's depiction of love tends to be crude as compared to July's People. Brandt Vermeulen is an Afrikaner who left the country for esteemed universities like Princeton to read politics. He develops views contrary to those held by other Afrikaners. For instance he despised the immorality act as out dated because sex across the racial lines defines a country rather than destroys it. Gordimer writes that, "the misplacement of the white man's semen in a black vagina would emerge transformed out of all recognition of source, as the birth of yet another nation." (175)

The description of love making here is by no means subtle. The narrator deliberately uses words like "semen" and "vagina" to make a point about the Immorality Act. These words are meant to jog the mind into seeing that the Immorality Act talks about things familiar to both races. On a deeper note semen and vagina show a sort of natural unity or belonging that cannot be held back by oppressive laws. Thus the urban setting here shows how blacks and whites can be separated not only physically but sexually as well. The explicit nature of Gordimer's descriptions brings attention to what is being discussed and exposes the manner in which the Act goes against natural impulses. There was no need for such language in July's People because the sexual relationships confine themselves to within the races. For instance the liaison that Maureen and July have with their respective spouses is on a marital level and hence is expected. Therefore, language can be manipulated to both shock and sensitize us through setting.- in this case the taboo of inter racial love making.

It is important to know that Gordimer's choice of language in describing love or even love making is directly associated with the level of violence in the setting. A few examples are the trials surrounding Rosa's family and the hanging of protestors in police cells. These can help us understand how the author depicts love making. There is an episode where Clare Terblanche and Rosa are having a conversation about the apartheid system. Rosa is angry that the struggle will be worthwhile only if a favorable outcome is guaranteed. Clare observes that "she looked the way I must have, for you, when described to me watching your mother and her lover fucking in the spare bedroom. She would deal with what was put before her without allowing herself to see it, just as I did.- it's part of the strategy of the struggle".(126) As is clearly shown here sex and struggle go hand in hand. Since the struggle is violent choice to follow so too the use of the word "fucking" shows the violence inherent. That is why I believe that the language in Burger's Daughter is manipulated to imitate the way of life in this urban setting.

\section{Conclusion}

This paper has sought to show that deviant sexual behavior was part of the African way of life. It has been shown that though homosexuality and lesbianism were practiced in pre-colonial and colonial Africa this did not warrant attention from writers of African literature.

Writers focused solely on issues that addressed what to them was the African condition in the midst of the white man's incursion. It was a condition that portrayed the African as economically, politically and spiritually emasculated by the noose of colonialism. However, there was the assumption that such an African was a sexual mannequin - without any notion of sexual identity other than procreation. For writers of African literature during the colonial era, the need to depict a sexual native let alone one who was promiscuous and sexually liberated (bisexual or heterosexual) went against the preferred narrative styles. This is odd in that if African writers wanted to show the detrimental effects of colonialism, the issue of homosexuality should have been explored essentially since it is alleged that the African homosexual is a myth It is only in the writings of the sixties when Africa was generally reaching the summit of the Independence rollercoaster that some writers dared to suggest that African sexual fulfillment could be a feature of the writing formulae. It is only in the later works that sexual expression becomes a feature of note in African literature. As such the works of the early African writers suggests that deviant sexual behavior was non-existent among the blacks and among the whites who lorded over many such Umofias and Dangans that Achebe and Oyono depict. It is in the literature of Southern Africa of the seventies that one sees a more brutal or candid depiction of the African's sexual identity and experience. 


\section{References}

Achebe, C. (1987). Anthills of the Savannah. Oxford: Heinemann Educational Publishers

Achebe, C. (1958). Things Fall Apart. London: Heinemann,

Amadi, E. (1966). The Concubine. Oxford: Heinemann Educational Publishers

Armah, A. (1974). Fragments. London: Heinemann Educational Books

Armah, A. (1973). Two Thousand Seasons. Oxford: Heinemann Educational Publishers

Aldrich, R. (2003). Colonialism and Homosexuality. London: Routledge

Chinodya, S. (1989). Harvest of Thorns. Heinemann: Johannesburg

Conrad, J. (1902). Heart of Darkness. London: Penguin Books

Epprecht, M. (2004). Hungochani, The History of a Dissident Sexuality in Southern Africa. London: McGill-Queen's University Press

Falk, K. '(1998). Homosexuality among the Natives of South West Africa.' Translated from 1926 German Publication by B. Rose and W. Roscoe, Boy-Wives, 187-96.

Farah, N. (1992).Sardines. Minnesota: Graywolf Press

Gordimer, N. (1980). Burgher's Daughter. Harmondsworth: Penguin

Gordimer, N. (1981). July's People. London: Penguin

Innes, C.L. (1990). Chinua Achebe. Cambridge: Cambridge University Press

Isaacs, G. Mckendrick, B. (1992).Male Homosexuality in South Africa, identity formation, culture and crisis. Oxford: Oxford University Press

Kakraba, D. (2011).“Ayei Kwei Armah’s Vulgar Language in The Beautiful Ones are Not Yet Born, A Therapeutic Tool”. Current Research Journal of Social Sciences 3(4): 306-313.

Lewis, A; Steyn, J.C. (2003). “A Critique of Mission Education in South Africa according to Bosch's mission paradigm theory". South African Journal of Education 23(2): 101-106

Marechera, D. (1978). House of Hunger. Oxford: Heinemann Educational Press

Murray, O. Roscoe, W. (1998). Boy-Wives and Female Homosexualities. London: Macmillan

Oyono, F. (1960). Houseboy. Oxford: Heinemann Educational Books

Plaatje, S. (1930). Mhudi. Oxford: Heinemann Educational Books

Rudwick,S. (2011). "Defying a Myth: A Gay subculture in Contemporary South Africa." Nordic Journal of African Studies 20(2): 90-111.

Thiong'o N. (1965). The River Between. Nairobi: Heinemann Educational Books

Thiong'o N. (1980). Devil on the Cross. Nairobi: Heinemann Educational Books

Venter ISJ. Die (1992).Sendingstasie Philipolis: 'n Histories opvoedkundige studie. Pretoria: Universiteit van Suid Africa.'

Wright, D. (1990). “Ayi Kwei Armah and the Significance of his Novels and Histories.” The_International Fiction Review 17.(1): 29-40. 